\title{
Helicobacter pylori in Gambian children with chronic diarrhoea and malnutrition
}

MRC Laboratories, Fajara,

The Gambia

P B Sullivan

T Corrah

B M Greenwood

Department of

Child Health,

University of

Newcastle upon Tyne

J E Thomas

Eastham

Departments of

Gastroenterology and

Histopathology,

Addenbrooke's Hospital,

Cambridge

D G D Wight

G Neale

Gambian Government/ MRC Joint

Research Unit

N Lloyd-Evans

Correspondence to:

Dr P B Sullivan,

Department of Child Health,

Westminster Children's

Hospital, Vincent Square,

London SW1P 2NS.

Accepted 17 October 1989

P B Sullivan, J E Thomas, D G D Wight, G Neale, E J Eastham, T Corrah, N Lloyd-Evans, B M Greenwood

\begin{abstract}
Infection with Helicobacter pylori (formerly Campylobacter pylori) was studied by measuring antibody titres to $\boldsymbol{H}$ pylori in Gambian children. Serological evidence of infection was found in 12 of $82(15 \%)$ infants aged less than 20 months; this increased to 62 of $135(46 \%)$ in those aged $40-60$ months. Positive serology was found in 41 of $77(53 \%)$ infants with chronic diarrhoea and malnutrition (mean age 19 months, range 5-36) compared with 18 of $70(26 \%)$ of age matched healthy controls and nearly a quarter (12/49, $24 \%$ ) of age matched undernourished (marasmic) subjects. These data show that infection with $H$ pylori is common in the Gambia and that in infancy this infection is associated with chronic diarrhoea and malnutrition.
\end{abstract}

Chronic diarrhoea and associated malnutrition is a major cause of childhood morbidity and mortality in developing countries. The pathogenesis of chronic diarrhoea and malnutrition is multifactorial, ${ }^{1}$ and it is often associated with infection of the gastrointestinal tract. In a small percentage of affected infants pathogenic bacteria such as Shigella spp, Salmonella spp and enteropathogenic Escherichia coli are found. ${ }^{2}$ More often micro-organisms of uncertain pathogenicity such as Giardia lamblia are identified. ${ }^{3}$ Finally in most cases of well established chronic diarrhoea and malnutrition the small intestine contains high concentrations of colonic bacteria, which contribute to small intestinal dysfunction. 56

The first major host defence against small bowel contamination, the gastric acid barrier, ${ }^{78}$ may be compromised in children with protein energy malnutrition. Gracey et al described gastritis and achlorhydria in eight out of nine patients with protein energy malnutrition and, although the cause of the gastritis was not established, it was attributed, in part, to high bacterial counts found in the gastric contents. ${ }^{9}$

Infection with Helicobacter pylori (formerly Campylobacter pylori) seems a likely aetiological agent. This organism causes an active chronic gastritis and, ${ }^{10}$ furthermore, it has become clear that $H$ pylori gastritis may be associated with a rise of fasting gastric $\mathrm{pH} .^{11-13}$ Diminished gastric acid output has persisted more than a year in several cases. ${ }^{14} \mathrm{H}$ pylori is found in adult populations around the world, ${ }^{15} 16$ but is uncommon in children in the Western world. ${ }^{17}$ The link between $H$ pylori infection, achlorhydric gastritis, and bacterial overgrowth in the small intestine in children with chronic diarr- hoea and malnutrition has not been investigated.

The aims of the study described in this paper were twofold: (1) to measure antibody titres to $H$ pylori in Gambian patients with $H$ pylori associated with gastritis, that had been proved histologically, so as to define antibody titres diagnostic of infection, and (2) to use serology to determine the prevalence of $H$ pylori infection in Gambian children with chronic diarrhoea and malnutrition and in controls.

\section{Subjects and methods}

VALIDATION OF SEROLOGICAL METHOD OF DIAGNOSING CHRONIC INFECTION WITH H PYLORI Fifty six subjects were examined for $H$ pylori infection: 36 were adults referred because of a long history of dyspepsia ( $16 \mathrm{men}, 20$ women, mean age 34.7 years) and 20 were children. Of the children 17 had chronic diarrhoea and malnutrition, one had toddler diarrhoea, one (aged 9 years) had chronic dyspepsia, and one had recurrent respiratory infections and marasmus. Gastroscopy was performed on these subjects (method in infants as described previously ${ }^{18}$ ) and four biopsy specimens of antral mucosa were taken. Two specimens were put in sterile phosphate buffered saline for microbiological culture and two were fixed in buffered formalin solution for histological examination.

Specific anti- $H$ pylori IgG was measured by enzyme linked immunoabsorbent assay (ELISA). ${ }^{19}$ The antigen was prepared from whole organisms, using strains from the National Collection of Type Cultures (NCTC) (11637 and 11916), and strains of organisms isolated from individuals in The Gambia. Test sera were run on plates with a standard calibration serum derived from pooled $H$ pylori positive sera from children in the United Kingdom. This serum was given an arbitrary ELISA value of 100 ELISA units. A calibration curve was constructed for each plate to allow each test serum to be given an ELISA value relative to the calibration serum. Each plate also had serial dilutions of a known negative control serum.

PREVALENCE OF ANTIBODIES TO $H$ PYLORI IN A RURAL GAMBIAN POPULATION

Stored sera from 361 children aged less than 5 years resident in villages near the town of Farafenni on the north bank of The Gambia river were available for study. These sera were obtained during a malaria survey undertaken in November 1986 and represented each child 
Table 1 Details of children with chronic diarrhoea and malnutrition and two control groups: well and malnourished

\begin{tabular}{|c|c|c|c|c|c|c|}
\hline \multirow[t]{2}{*}{ Group } & \multicolumn{2}{|l|}{ Age (months) } & \multirow{2}{*}{$\begin{array}{l}\text { Sex } \\
(M / F)\end{array}$} & \multirow{2}{*}{$\begin{array}{l}\text { No with marasmus/ } \\
\text { marasmic- } \\
\text { Kwashiorkor }\end{array}$} & \multicolumn{2}{|c|}{ Weight for heightt } \\
\hline & Mean $(S D)$ & Range & & & Mean $(S D)$ & Range \\
\hline $\begin{array}{l}\text { Chronic diarrhoea and } \\
\text { malnutrition }(\mathrm{n}=77)\end{array}$ & $19 \cdot 0(6 \cdot 3)$ & $5-36$ & $40 / 37$ & $55 / 22$ & $65 \cdot 1(7 \cdot 9)$ & $47-90$ \\
\hline $\begin{array}{l}\text { Well }(n=70) \\
\text { Malnourished* }(n=49)\end{array}$ & $\begin{array}{l}18 \cdot 3(8 \cdot 6) \\
19 \cdot 4(7 \cdot 7)\end{array}$ & $\begin{array}{l}6-36 \\
6-35\end{array}$ & $\begin{array}{l}40 / 30 \\
25 / 24\end{array}$ & $\overline{29 / 0}$ & $\begin{array}{l}95 \cdot 7(3 \cdot 7) \\
67 \cdot 2(4 \cdot 9)\end{array}$ & $\begin{array}{l}92-103 \\
58-74\end{array}$ \\
\hline
\end{tabular}

${ }^{*}$ These children had protein energy malnutrition.

t\% NCHS median.

from every fifth compound in their respective villages. Basic demographic and anthropometric data were collected during the survey.

\section{PREVALENCE OF ANTIBODIES TO $H$ PYLORI IN CHILDREN WITH CHRONIC DIARRHOEA AND MALNUTRITION}

Samples of sera were obtained from three groups of children: 77 with chronic diarrhoea and malnutrition; 70 asymptomatic well nourished children (weight for height $>90 \%$ National Center for Health Statistics (NCHS) median value), and 49 malnourished children without diarrhoea (table 1). Chronic diarrhoea was defined as diarrhoea with more than three loose stools/day for more than two weeks and protein energy malnutrition when the weight for height fell below $75 \%$ of the NCHS median value. In patients with chronic diarrhoea and malnutrition the mean duration of diarrhoea was 12 weeks (range two to 52 weeks). The three groups were well matched for age and sex.

Marasmic control patients were recruited from the ward and outpatient department at the Medical Research Council (MRC) hospital in Fajara, and healthy controls were obtained with the help of field workers from the adjacent township of Bakau and from rural villages around Farafenni. Similar proportions of the groups of marasmic and healthy control children came from either a rural or an urban environment. $H$ pylori infection was determined serologically and its prevalence in the three groups compared.

The protocol for the study was approved by the committee on human experimentation of the MRC Laboratories in The Gambia. Statistical analysis was performed by the $\chi^{2}$ test and the $t$ test where appropriate.

\section{Results}

ANTIBODIES TO $H$ PYLORI IN PATIENTS UNDERGOING ENDOSCOPY

Antibodies to $H$ pylori were measured in 36 adults and in 20 children who underwent gastrointestinal endoscopy. Satisfactory antral biopsies were obtained from 34 adult patients; 33 had antral gastritis. $H$ pylori was identified in 32 patients by examination of Giemsa stained tissue sections (32/34) and Gram stained wet preparations (28/34). The organism was grown in pure culture from three patients. No bacteria were identified on the mucosa of the one patient with normal histology. Titres of specific anti$H$ pylori (NCTC) IgG were greater than 100 ELISA units in all adult patients in whom $H$ pylori were identified. Similar results were obtained with antigens prepared from the
NCTC strain of $H$ pylori and the Gambian isolates. A similar association between raised antibody titres to $H$ pylori and the demonstration of the bacterium on gastric mucosa was found in children. Sixteen of the 20 children endoscoped had antral gastritis. Eleven children had $H$ pylori on their antral mucosa. Circulating IgG antibodies against $H$ pylori were found in 13 children all of whom had antral gastritis ( $H$ pylori identified histologically in eight). They were not found in seven children: including all four with a histologically normal antral mucosa, two with atrophic gastritis but without $H$ pylori, and in only one with gastritis and $H$ pylori (table 2).

The titre of circulating antibodies exceeded 100 ELISA units in all adults and in eight out of the 13 children in whom $H$ pylori was identified. In the remaining five infants the titre was more than 40 ELISA units dilution. Based on these findings in adults and children we concluded that an antibody titre of 100 ELISA units or greater strongly suggests an active infection with $H$ pylori.

\section{ANTIBODIES TO $H$ PYLORI IN GAMBIAN VILLAGE} CHILDREN

The prevalence of antibodies to $H$ pylori at a titre of 100 ELISA units or greater in Gambian village children is shown in table 3 . The prevalence of a raised antibody titre increased from $15 \%(12 / 82)$ children aged 0-19 months, to $27 \%$ (37/136) of those aged $20-39$ months, and to $46 \%(62 / 135)$ in those children aged 40-60 months. Anthropometric data was available on these children and in those below 30 months of age there was a significant effect of malnutrition on the prevalence of high anti- $H$ pylori antibody

Table 2 Correlation of anti-H pylori IgG with histological findings in gastric mucosa $(n=20)$

\begin{tabular}{lll}
\hline & $\begin{array}{l}\text { H pylori } \\
\text { present }\end{array}$ & $\begin{array}{l}\text { H pylori } \\
\text { absent }\end{array}$ \\
\hline $\begin{array}{l}\text { Antral gastritis (n=16) } \\
\text { Antibody titre (ELISA units): }\end{array}$ & 9 & 7 \\
$\quad \begin{array}{l}>100 \\
\text { 10-100 }\end{array}$ & 8 & - \\
$\begin{array}{l}\text { Negative } \\
\text { No antral inflammation }(\mathrm{n}=4)^{*}\end{array}$ & $\frac{1}{2}$ & $\frac{5}{2}$ \\
\hline
\end{tabular}

${ }^{*}$ All four were negative on ELISA.

Table 3 Age related prevalence of anti-H pylori antibody titres

\begin{tabular}{ll}
\hline Age range (months) & $\begin{array}{l}\text { Specific IgG titre }>100 \text { ELISA units } \\
(\% \text { prevalence) }\end{array}$ \\
\hline $0-19$ & $12 / 82(15)$ \\
$20-39$ & $37 / 136(27)$ \\
$40-60$ & $62 / 135(46)$ \\
\hline
\end{tabular}


titres. In this group 11 of $39(28 \%)$ of those with marasmus (weight for height $<75 \%$ NCHS median value) had antibody titres of 100 ELISA units or more compared with only 14 of 116 $(12 \%)$ of those in the same age group who were well nourished $\left(\chi^{2}=4 \cdot 488,1 \mathrm{df}, \mathrm{p}<0.03\right)$. This effect of malnutrition was not seen in the children over 30 months of age.

\section{ANTIBODIES TO $H$ PYLORI IN CHILDREN WITH CHRONIC DIARRHOEA AND MALNUTRITION AND CONTROLS}

Antibodies to $H$ pylori at a titre of 100 ELISA units or greater were found significantly more frequently in children with chronic diarrhoea and marasmus $(41 / 77,53 \%)$ than in children with maramus but no diarrhoea $(12 / 49,24 \%)$ or than in healthy age matched control children $(18 / 70,26 \%)\left(\chi^{2}=9 \cdot 0,1 \mathrm{df}, \mathrm{p}<0.01\right.$ and $\chi^{2}=$ $10.5,1 \mathrm{df}, \mathrm{p}<0.01$ respectively). Seventeen of the children with chronic diarrhoea and malnutrition also underwent endoscopy. $H$ pylori was demonstrated on the mucosa of 10 of these children.

\section{Discussion}

In this study we have shown the value of the serological diagnosis of $H$ pylori in the community under study and demonstrated that infection of the gastric mucosa with $H$ pylori is established early in life in many children in The Gambia. The high anti- $H$ pylori antibody titres found in The Gambia may reflect chronic infection and therefore prolonged antigenic stimulation. In a random population antibodies were found in $46 \%$ of children aged $40-60$ months. In Britain the prevalence of infection in this age group is unknown but preliminary data from Newcastle suggests that it is around $1 \%$ and less than $6 \%$ for the age group $5-16$ years. ${ }^{17}$ The route of acquisition of $H$ pylori infection is not yet established, but it is possible that person to person contact is involved. ${ }^{20-22}$ Living conditions in The Gambia and especially feeding practices whereby children eat by hand from a communal bowl may favour the spread of $H$ pylori and contribute to the high prevalence rate observed. Children in the tropics with chronic diarrhoea and associated malnutrition represent such a heterogenous group that obtaining adequate control groups for any study is difficult. This is illustrated by the apparent association between the prevalence of high anti$H$ pylori antibody titres and malnutrition in Farafenni children less than 30 months of age. This finding is, however, confounded by the fact that many of the malnourished children in this group also had concurrent diarrhoea. Therefore, an attempt was made in this study to control for the effects of both diarrhoea and malnutrition alone. Children with marasmus and no diarrhoea were not found to have a higher prevalence of $H$ pylori infection than healthy children of the same age, whereas in the patients with marasmus in association with chronic diarrhoea, there was a significantly increased prevalence rate of $H$ pylori infection compared with matched control groups. Chronic diarrhoea in association with marasmus may predispose to $H$ pylori infection due to the fact that children with chronic diarrhoea and malnutrition are more unwell and more immunocompromised than children with marasmus alone. Alternatively, $H$ pylori infection itself may predispose to enteritis with other organisms by compromising the gastric acid barrier. It is also possible that both factors operate. The association between gastritis associated with $H$ pylori and hypochlorhydria is controversial. ${ }^{23}$ Nevertheless, even a transient impairment of the gastric acid barrier at the time of infection could predipose to small bowel bacterial overgrowth and recurrent enteritis and may represent an important aspect of the pathogenesis of chronic diarrhoea and malnutrition in children in The Gambia. Further investigations of the relation between gastric $H$ pylori infection, gastric acidity, and small bowel bacterial overgrowth in children with chronic diarrhoea and malnutrition are indicated.

We would like to thank the medical and nursing staff of the ward at Fajara for their unstinting cooperation. This work was funded in part by a grant from the Thrasher Research Fund, Salt Lake City, Utah, USA (PBS) and in part by a Children Nationwide Paediatric Fellowship (JET).

1 McNeish AS. Chronic diarrhoea-a model for discussion. In: McNeish AS, Walker-Smith J, eds. Diarrhoea and malnutrition in childhood. London: Butterworths, 1986:1-6.

2 Ulshen MH, Rollo JR. Pathogenesis of $\mathrm{E}$ coli gastroenteritis

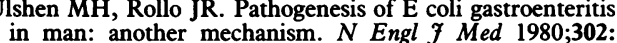
in man:

3 Mata LJ. The children of Santa Maria Cauque: a prospective field study of health and growth. Boston: The MIT Press,

4 Sullivan PB, Neale G. Farthing MJ, Goka J. The diagnosis of giardia infection in the tropics. Gut 1988;29:A1476.

5 Gracey $M$, Stone DE. Small intestinal microflora in Australian Aboriginal children with chronic diarrhoea. Aust NZ F Med 1972;3:215-9.

6 Kern SE, Keren DF, Pierson CL. Bacterial overgrowth and mucosal changes in isolated (Thiry-Vella) ileal loops in rabbits. Lab Invest 1987;57:336-41.

7 Gilman RH, Partanen R, Brown KH, et al. Decreased gastric acid secretion and bacterial colonization of the stomach in severely malnourished Bangladeshi children. Gastroenterology 1988;94:1308-14.

8 Giannella RA, Broitman SA, Zamcheck N. Gastric acid barrier to ingested microorganisms in man: studies in vivo barrier to ingested microorganisms in

9 Gracey M, Cullity CJ, Suharyono S. The stomach in malnutrition. Arch Dis Child 1977;52:325-7.

10 Warren JR, Marshall B. Unidentified curved bacilli on gastric epithelium in active chronic gastritis. Lancet 1983;i:1273-5.

11 Morris A, Nicholson G. Ingestion of Campylobacter pyloridis causes gastritis and raised fasting gastric $\mathrm{pH}$. Am $\mathcal{J}$ Gastroenterol 1987;82:192-9.

12 Graham DY, Smith JL, Alpert LC, et al. Epidemic achlorhydria is not viral but is caused by Campylobacter pyloridis. Gastroenterology 1987;92:1412.

13 Cave DR, Vargas M. Effect of a Campylobacter pylori protein on acid secretion by parietal cells. Lancet 1989;ii:187-9. 4 Gledhill T, Leicester RJ, Addis B, et al. Epidemic hypochlorhydria $\mathrm{Br}$ Med $\mathcal{F}$ 1985;290:1383-6.

15 Wyatt JI, de Caestecker JS, Rathbone BJ, Heatley RV. C pyloridis in tropical Africa. Gut 1987;28:A1409-10.

16 Daskalopoulos G. Borody T, Carrick KJ, Ralston M, Hazell S. Relationship of patient's country of origin to endoscopic frequency of $\mathrm{C}$ pyloridis gastritis. Gastroenterology 1987;92:A1363.

17 Thomas JE, Eastham EJ, Elliott TSJ, Dobson CM, Berkeley $D$. The prevalence of $C$ pylori infection in childhood and its relation to symptoms. Gut 1988;29:A707.

18 Sullivan PB, Phillips MB, Neale G. Endoscopic capsule biopsy of the small intestine. $\mathcal{F}$ Pediatr Gastroenterol Nutr 1988;7:544-7.

19 Jones DM, Eldridge J, Fox AJ, Sethi P, Whorwell PJ. Antibodies to the gastric campylobacter-like organism (C pyloridis)-clinical correlation and distribution in the normal population. $\mathcal{F}$ Med Microbiol 1986;22:57-62.

20 Berkowicz J, Lee A. Person-to-person transmission of C pylori. Lancet 1987;ii:680-1.

21 Mitchell HM, Bohane TD, Berkowicz J, Hazell S, Lee A Antibody to $\mathrm{C}$ pylori in families of index children with gastrointestinal illness due to $C$ pylori. Lancet 1987;ii: 681-2.

22 Jones DM, Eldridge J, Whorwell PJ. Antibodies to Campylobacter pyloridis in household contacts of infected patients. $\mathrm{Br}$ Med F 1987;294:615.

23 Wagner S, Freise J, Beholz S, Werner Schmidt F. Campylobacter pylori and gastric acidity. Am $\mathcal{F}$ Gastroenterol 1989;84:201-2. 